\title{
PENGARUH KONTRAK UTANG, BIAYA POLITIK, DAN ASIMETRI INFORMASI TERHADAP KEPUTUSAN REVALUASI ASET TETAP
}

\author{
Oktavia Velicia Cindy Wibowo \\ Lindrawati* \\ Universitas Katolik Widya Mandala Surabaya, Jalan Dinoyo 42-44, Surabaya \\ lindrawati@ukwms.ac.id
}

\author{
A R T I C L E I N F O \\ Article history: \\ Received February 20, 2019 \\ Revised March 14, 2019 \\ Accepted March 29, 2019
}

Key words:

Debt contract, Political cost, Information asymmetry, Fixed asset revaluation, Market response

\begin{abstract}
A B S T R A C T
The revaluation model had been regulated in PSAK Number 16 and is believed to be more relevant as it presents the asset value according to its true value so it is expected to generate a market response due to an increase in asset value. Therefore this research aims to examine and analyze the effect of debt contracts, political costs, and information asymmetry on fixed asset revaluation decisions. Additional tests were conducted to analyze differences in market responses of firms that revalued fixed assets and did not revalue fixed assets. The research design is based on quantitative research using hypothesis and used quantitative data in the form of financial statements, announcement date of financial statements, closing prices, and Indonesia Composite Index. The research object is all manufacturing companies listed on the IDX in 2012-2016. Data analysis technique for main model is logistic regression and data analysis technique for additional test is Mann-Whitney $U$ test. The result of the research indicates that debt contract has no effect on fixed asset revaluation, political costs have a positive effect on fixed asset revaluation, and information asymmetry has a negative effect on fixed asset revaluation. The additional test proves that there is no difference in the market response of the company that did the revaluation and did not revalue because the increase in asset value was not due to the increase in performance so that the revaluation of the fixed asset is not considered as useful information.
\end{abstract}

\section{A B S T R A K}

Model revaluasi telah diatur dalam PSAK No. 16 dan diyakini lebih relevan karena menyajikan nilai aset sesuai dengan nilai sebenarnya sehingga diharapkan untuk menghasilkan respons pasar karena peningkatan nilai aset. Oleh karena itu penelitian ini bertujuan untuk menguji dan menganalisis pengaruh kontrak utang, biaya politik, dan asimetri informasi pada keputusan revaluasi aset tetap. Tes tambahan dilakukan untuk menganalisis perbedaan respons pasar perusahaan yang merevaluasi aset tetap dan tidak merevaluasi aset tetap. Desain penelitian didasarkan pada penelitian kuantitatif menggunakan hipotesis dan menggunakan data kuantitatif dalam bentuk laporan keuangan, tanggal pengumuman laporan keuangan, harga penutupan, dan Indeks Harga Saham Gabungan. Objek penelitian adalah semua perusahaan manufaktur yang terdaftar di BEI pada 2012-2016. Teknik analisis data untuk model utama adalah regresi logistik dan teknik analisis data untuk tes tambahan adalah uji Mann-Whitney U. Hasil penelitian menunjukkan bahwa kontrak utang tidak berpengaruh terhadap revaluasi aset tetap, biaya politik berpengaruh positif terhadap revaluasi aset tetap, dan asimetri informasi berpengaruh negatif terhadap revaluasi aset tetap. Uji tambahan membuktikan bahwa tidak ada perbedaan dalam respon pasar perusahaan yang melakukan revaluasi dan tidak melakukan revaluasi karena kenaikan nilai aset bukan karena peningkatan kinerja sehingga revaluasi aset tetap tidak dianggap sebagai informasi berguna.

\section{PENDAHULUAN}

Laporan keuangan yang relevan dan andal akan membantu perusahaan mendapatkan dana karena mampu meningkatkan kepercayaan investor terhadap perusahaan. Dana yang diperoleh perusahaan akan diinvestasikan pada aset lancar maupun aset tetap yang berguna untuk mendukung operasi perusahaan. Aset lancar adalah kas dan aset lain yang dapat dikonversi menjadi kas, dijual, atau dikonsumsi dalam satu tahun atau satu 
siklus operasi, yang mana yang lebih panjang (Kieso, Weygandt dan Warfield, 2014). Berbeda dengan aset lancar, aset tetap tidak memenuhi kriteria tersebut. Berdasarkan Pernyataan Standar Akuntansi Keuangan (PSAK) Nomor 16, aset tetap merupakan aset berwujud yang: (a) dimiliki untuk digunakan dalam produksi atau penyediaan barang atau jasa untuk direntalkan kepada pihak lain, atau untuk tujuan administratif; dan (b) diharapkan untuk digunakan selama lebih dari satu periode (Ikatan Akuntan Indonesia (IAI), 2017). Aset tetap digunakan perusahaan dalam periode yang panjang sehingga diperlukan peraturan khusus dalam pencatatan aset tetap.

Pada pengakuan awal, aset tetap diukur sebesar biaya perolehan, yaitu biaya yang dikeluarkan perusahaan untuk memperoleh aset tetap hingga aset siap digunakan. Kemudian pada pengukuran setelah pengakuan awal, aset tetap dapat diukur dengan model biaya (IAI, 1994). Dengan model biaya, aset tetap disajikan sebesar biaya perolehan dikurangi akumulasi penyusutan dan akumulasi rugi penurunan nilai. Model ini memiliki kelebihan dalam hal keandalan karena nilainya diperoleh dari transaksi dimasa lalu sesuai dengan kesepakatan antara penjual dan pembeli dengan bukti transaksi yang dapat diverifikasi. Namun model biaya dinilai kurang relevan karena nilai tercatat aset tetap akan berbeda dengan nilai pasar aset sekarang. PSAK Nomor 16 (IAI,1994) menyatakan revaluasi aset tetap tidak diperkenankan karena menggunakan harga perolehan, namun penyimpangan dari ketentuan ini mungkin dapat dilakukan berdasarkan ketentuan pemerintah (IAI, 1994). Hal ini menunjukkan bahwa revaluasi aset tetap dapat dilakukan untuk tujuan perpajakan sesuai peraturan pemerintah dan tidak terdapat uraian lebih lanjut terkait revaluasi aset tetap dalam PSAK Nomor 16. Namun sejak konvergensi International Financial Reporting Standards (IFRS), PSAK Nomor 16 (IAI revisi, 2007) mengadopsi International Accounting Standards (IAS) Nomor 16 (IAI, 2003) dan memberikan pilihan kebijakan akuntansi terkait pengukuran setelah pengakuan awal aset tetap, yaitu model biaya dan model revaluasi. Dengan model revaluasi, aset tetap disajikan sebesar nilai wajar saat revaluasi dikurangi akumulasi penyusutan dan akumulasi rugi penurunan nilai. Model revaluasi mampu mengatasi kelemahan model biaya karena model revaluasi dinilai dapat mencerminkan keadaaan yang sebenarnya dari aset. Revaluasi aset tetap dalam praktiknya mencatat aset menggunakan nilai pasar dari aset tersebut, sehingga nilai aset menjadi relevan (Yulistia, Fauziati, Minovia, dan Khairati, 2015).

Walaupun dinilai lebih relevan karena mampu menunjukkan nilai aset yang sebenarnya, sebagian besar perusahaan di Indonesia masih menggunakan model biaya. Sejak PSAK Nomor 16 (IAI revisi, 2007) berlaku efektif, hanya lima perusahaan manufaktur yang melakukan revaluasi pada tahun 2008, sedangkan pada tahun 2009 hanya terdapat tiga perusahaan manufaktur yang melakukan revaluasi (Yulistia dkk., 2012; dalam Yulistia dkk., 2015). Bahkan hingga tahun 2015, hanya terdapat 20 perusahaan manufaktur yang menggunakan model revaluasi (Purnamasari, 2017). Peningkatan ini menunjukkan semakin banyak perusahaan manufaktur yang memahami pentingnya menyajikan laporan keuangan yang relevan, namun hal ini masih menunjukkan bahwa sebagian besar perusahaan manufaktur di Indonesia masih enggan memilih model revaluasi karena besarnya biaya yang harus dikeluarkan perusahaan untuk merevaluasi aset tetap, seperti biaya pajak dan biaya appraisal. Ketika melakukan revaluasi, surplus revaluasi yang muncul merupakan objek pajak penghasilan dan dikenai PPh final sebesar $10 \%$ (Peraturan Menteri Keuangan Nomor 79/PMK.03/2008 Pasal 5). Biaya lain, yaitu biaya appraisal, menjadi biaya yang harus dikeluarkan perusahaan karena berdasarkan Keputusan Ketua Badan Pengawas Pasar Modal dan Lembaga Keuangan Nomor 347/BL/2012 tentang Penyajian dan Pengungkapan Laporan Keuangan Emiten atau Perusahaan Publik, perusahaan publik yang memilih model revaluasi harus menggunakan penilaian dari Kantor Jasa Penilai Properti (KJPP) yang terdaftar di Bapepam dan LK.

Pemilihan model revaluasi dipengaruhi oleh beberapa faktor, diantaranya adalah: kontrak utang, biaya politik, dan asimetri informasi (Yulistia dkk., 2015; Andison, 2015; Seng dan Su, 2010; Tay, 2009). Faktor pertama yaitu kontrak utang adalah perjanjian antara debitor dan kreditor yang bertujuan untuk melindungi kreditor dari risiko default. Salah satu bentuk perjanjian ini adalah batasan-batasan (threshold) rasio keuangan yang harus dipatuhi oleh debitor. Semakin dekat perusahaan dengan batasan kontrak utang, semakin tinggi pula risiko yang dihadapi perusahaan karena berpeluang besar melanggar perjanjian kontrak utang. Manajemen akan berupaya agar tidak terjadi pelanggaran perjanjian kontrak utang dengan memilih kebijakan akuntansi yang mampu memperbaiki rasio tersebut. Perusahaan yang berpeluang besar melanggar perjanjian kontrak utang akan 
memilih model revaluasi sehingga pelanggaran kontrak utang dapat dihindari (Seng dan Su, 2010).

Faktor kedua yaitu biaya politik merupakan biaya yang dikeluarkan perusahaan dalam rangka memenuhi tuntutan pihak eksternal, seperti pemerintah dan serikat buruh terhadap perusahaan. Biaya politik yang tinggi menunjukkan bahwa perusahaan tersebut mendapatkan perhatian politik yang tinggi dari pihak eksternal, di mana hal ini biasanya dialami oleh perusahaan besar. Berdasarkan hipotesis biaya politik (political cost hypothesis), perusahaan besar akan cenderung memilih kebijakan akuntansi yang menurunkan laba untuk mengurangi perhatian politik (Watts dan Zimmerman, 1990). Perusahaan dengan biaya politik tinggi akan berusaha mengurangi laba, salah satunya dengan memilih model revaluasi yang menyebabkan peningkatan biaya depresiasi. Penurunan laba ini diharapkan mampu mengurangi perhatian politik yang diberikan pihak eksternal terhadap perusahaan (Lin dan Peasnell, 2000; dalam Seng dan Su, 2010).

Faktor ketiga adalah asimetri informasi yaitu ketika pihak internal memiliki informasi yang lebih banyak dibandingkan dengan pihak eksternal. Asimetri informasi tersebut dapat dikurangi ketika perusahaan menyajikan informasi sebenarnya yang tidak diketahui pihak eksternal. Dalam rangka mengurangi asimetri informasi, manajer akan cenderung memilih model revaluasi karena lebih relevan dan menyajikan nilai aset tetap dengan lebih jujur (relevant and faithful representation). Dengan memilih menggunakan nilai wajar, perusahaan bertujuan menunjukkan nilai perusahaan sesungguhnya (true value) untuk mengurangi asimetri informasi (Farahmita dan Siregar, 2014).

Keputusan memilih model revaluasi aset tetap dalam laporan keuangan akan menjadi informasi bagi pihak eksternal (Andison, 2015). Informasi ini berpeluang menimbulkan respons pasar karena revaluasi aset tetap akan menunjukkan nilai aset yang sebenarnya dan meningkatkan nilai aset perusahaan. Berdasarkan hipotesis pasar efisien, informasi yang bermanfaat akan direspons oleh pasar dan tercermin dari perubahan harga saham (Bandi dan Hartono, 1999). Jika keputusan revaluasi berguna dan disukai oleh pemegang saham, maka pemegang saham akan memberikan respons positif sehingga harga saham meningkat. Informasi revaluasi dapat memberikan sinyal kepada investor bahwa mereka memiliki peluang untuk memperoleh keuntungan atas investasinya, baik dalam bentuk return maupun abnormal return (Andison, 2015). Oleh sebab itu dilakukanlah uji tambahan untuk menguji adanya perbedaan respons pasar pada perusahaan yang melakukan revaluasi aset tetap dan tidak melakukan revaluasi aset tetap.

Objek penelitian adalah perusahaan manufaktur yang terdaftar di Bursa Efek Indonesia (BEI) pada tahun 2012-2016. Perusahaan manufaktur digunakan sebagai objek penelitian karena perusahaan manufaktur memiliki proporsi aset tetap yang relatif lebih tinggi dibandingkan dengan sektor lainnya sehingga pemilihan model revaluasi akan mempengaruhi nilai aset di laporan posisi keuangan secara material. Penelitian dimulai pada tahun 2012 karena tahun 2012 konvergensi IFRS telah diberlakukan dan diterapkan secara penuh di Indonesia. Penelitian ini diakhiri pada tahun 2016 agar hasil penelitian lebih relevan dengan keadaan saat ini.

Berdasarkan penjelasan pada latar belakang, maka rumusan masalah penelitian adalah: "Apakah kontrak utang, biaya politik, dan asimetri informasi berpengaruh terhadap keputusan revaluasi aset tetap pada perusahaan manufaktur yang terdaftar di BEI periode 2012-2016?" Penelitian ini dilakukan dengan tujuan untuk menguji dan menganalisis pengaruh kontrak utang, biaya politik, dan asimetri informasi terhadap keputusan revaluasi aset tetap pada perusahaan manufaktur yang terdaftar di BEI periode 2012-2016.

Penelitian ini dilakukan dengan harapan dapat memberikan manfaat sebagai berikut:

1. Manfaat akademis, sebagai acuan bagi penelitian berikutnya dengan topik sejenis yaitu pengaruh kontrak utang, biaya politik, dan asimetri informasi terhadap keputusan revaluasi aset tetap pada perusahaan manufaktur yang terdaftar di BEI periode 2012- 2016.

2. Manfaat praktis

Sebagai bahan pertimbangan bagi investor agar mempertimbangkan pengaruh kontrak utang, biaya politik, dan asimetri informasi terhadap keputusan revaluasi aset tetap dalam rangka mengambil keputusan investasi sehingga dapat memaksimalkan return.

Sebagai masukan bagi Dewan Standar Akuntansi Keuangan terkait faktor-faktor yang mempengaruhi revaluasi aset tetap sehingga dapat digunakan sebagai masukan untuk revisi PSAK Nomor16 di masa depan dalam hal pengungkapan dampak revaluasi aset tetap atas kontrak utang, biaya politik, dan asimetri informasi. 
KAJIAN LITERATUR DAN PENGEMBANGAN HIPOTESIS

Teori Akuntansi Positif

Teori akuntansi positif mempelajari apa yang nyatanya dilakukan para pelaku ekonomi dan alasan mereka berbuat demikian (Suwardjono, 2008). Teori ini menyatakan bahwa manajemen akan memilih kebijakan akuntansi yang membantu mereka mencapai tujuan tertentu (Khairati, Muslim, dan Darmayanti, 2015). Watts dan Zimmerman (1990) menemukan bahwa motivasi manajer dalam memilih suatu metode atau kebijakan akuntansi didasarkan oleh bebeberapa hipotesis, yaitu:

1. Hipotesis rencana bonus (bonus plan hypothesis), menyatakan bahwa manajer akan berupaya mendapatkan bonus dengan memilih kebijakan akuntansi yang meningkatkan laba.

2. Hipotesis perjanjian utang (debt covenant hypothesis), menyatakan bahwa manajer akan memilih metode akuntansi yang menghindarkan perusahaan dari pelanggaran perjanjian konrak utang.

3. Hipotesis biaya politik (political cost hypothesis), menyatakan bahwa perusahaan besar akan cenderung menggunakan kebijakan akuntansi yang mengurangi laba. Ukuran perusahaan merupakan proksi yang digunakan untuk mengukur perhatian politik.

\section{Kontrak Utang}

Kontrak utang adalah sebuah perjanjian yang dirancang untuk melindungi pemberi pinjaman dan dalam keadaan tertentu dapat mengurangi kemampuan manajemen untuk mengambil keputusan yang menguntungkan perusahaan secara keseluruhan (Nikolaev, 2006). Kontrak utang dibuat untuk menyelesaikan konflik kepentingan antara kreditor dan investor dengan debitor. Manajemen akan berupaya memaksimalkan kepentingan pemegang saham. Pemegang saham tentunya mengharapkan return yang baik, misalnya berupa pembagian dividen. Namun pembagian dividen ini dapat mempengaruhi kemampuan perusahaan dalam membayar utang kepada kreditor sehingga merugikan kreditor. Untuk menghindari konflik tersebut, dibuatlah sebuah perjanjian kontrak yang memberikan batasanbatasan pada perusahaan untuk menjaga kemampuan perusahaan dalam melunasi utangnya. Bentuk batasan- batasan tersebut dapat berupa batasan dalam rasio keuangan, seperti debt to EBITDA, fixed charge coverage, interest coverage, leverage ratio, debt to equity ratio, debt to tangible net worth, current ratio, quick ratio (Chava dan Roberts, 2008).

Semakin dekat perusahaan dengan batasan rasio, semakin besar risiko perusahaan untuk melakukan pelanggaran atas kontrak utang dan dapat mengakibatkan kreditor mempercepat jatuh tempo utangnya atau memilih tindakan yang paling menguntungkan pihaknya (Chava dan Roberts, 2008). Hipotesis kontrak utang memprediksi bahwa semakin besar kemungkinan sebuah perusahaan melanggar perjanjian kontrak, semakin kuat insentif manajemen untuk terlibat dalam proses pelaporan keuangan agar dapat menghindari pelanggaran tersebut (Dichev dan Skinner, 2002).

\section{Biaya Politik}

Biaya politik merupakan biaya yang dikeluarkan perusahaan dalam rangka memenuhi tuntutan pihak eksternal akibat besarnya laba perusahaan (Milne, 2002). Hipotesis biaya politik menyatakan bahwa perusahaan besar akan cenderung memilih kebijakan akuntansi yang menurunkan laba untuk mengurangi perhatian politik (Watts dan Zimmerman, 1990). Pada dasarnya, biaya politik yang tinggi akan dihadapi oleh perusahaan besar karena perusahaan besar cenderung mendapatkan perhatian dan tekanan yang tinggi dari pemerintah, serikat buruh, dan kelompok komunitas (Chainirun dan Narktabtee, 2009). Dalam rangka mengurangi perhatian politik tersebut, perusahaan akan memilih metode akuntansi yang menurunkan laba. Pilihan perusahaan untuk melakukan revaluasi merupakan salah satu cara yang ditempuh karena dengan melakukan revaluasi aset tetap, beban depresiasi akan meningkat karena nilai aset yang dijadikan dasar penyusutan aset bertambah. Peningkatan beban depresiasi diharapkan dapat mengurangi perhatian dan tuntutan pihak eksternal seperti peningkatan beban pajak dan tuntutan serikat buruh atas kenaikan upah.

\section{Asimetri Informasi}

Asimetri informasi merupakan keadaan dimana pengguna eksternal tidak dapat memperoleh informasi lengkap karena perbedaan antara informasi yang dilaporkan dengan realitas ekonomi perusahaan (Seng dan Su, 2010). Terdapat dua jenis asimetri informasi (Scott, 2014), yaitu:

1. Adverse selection adalah jenis asimetri 
informasi di mana pihak yang melangsungkan usaha memiliki informasi lebih daripada pihak-pihak lain. Adverse selection terjadi karena manajer perusahaan dan para pihak dalam (insider) lainnya lebih mengetahui prospek masa depan perusahaan dibandingkan pihak luar.

2. Moral hazard adalah jenis asimetri informasi di mana pihak yang melangsungkan usaha atau transaksi usaha potensial dapat mengamati tindakan mereka sedangkan pihak lainnya tidak. Moral hazard muncul karena pemisahan peran pemilik dan pengelola perusahaan.

\section{Aset Tetap}

Aset tetap berdasarkan PSAK Nomor 16 merupakan aset berwujud yang: (a) dimiliki untuk digunakan dalam produksi atau penyediaan barang atau jasa untuk direntalkan kepada pihak lain, atau untuk tujuan administratif; dan (b) diharapkan untuk digunakan selama lebih dari satu periode (IAI, 2017). Aset tetap diakui perusahaan ketika aset tetap tersebut dikuasai oleh perusahaan. Penguasaan berarti kemampuan perusahaan untuk mendapatkan, memelihara/menahan, menukarkan, menggunakan manfaat ekonomik dan mencegah akses pihak lain terhadap manfaat tersebut (Suwardjono, 2008). Konsep penguasaan ini lebih luas daripada konsep kepemilikan, karena aset tetap yang dikuasai perusahaan belum tentu milik perusahaan secara hukum, misalnya dalam sewa guna pendanaan (finance lease). Secara hukum, aset tersebut merupakan milik lessor, tetapi secara substansi, aset tersebut dikuasai oleh lessee. Hal ini menunjukkan banyak cara untuk memperoleh aset tetap. Aset tetap dapat diperoleh oleh entitas dengan beberapa cara, yaitu: pembelian, pemberian, penemuan, perjanjian, produksi, penjualan, dan peminjaman (Most, 1982; dalam Suwardjono, 2008).

\section{Revaluasi Aset Tetap}

Revaluasi aset tetap adalah penilaian kembali aset tetap perusahaan, yang diakibatkan adanya kenaikan nilai aset tetap tersebut di pasaran atau karena rendahnya nilai aset tetap dalam laporan keuangan perusahaan yang disebabkan oleh devaluasi atau sebab lain sehingga nilai aset tetap dalam laporan keuangan perusahaan tidak lagi mencerminkan nilai yang wajar (Waluyo, 2014). Revaluasi aset tetap merupakan proses penilaian ulang aset tetap yang mencerminkan nilai wajar aset pada tanggal revaluasi. Revaluasi aset tetap bertujuan agar nilai aset yang disajikan di laporan keuangan semakin mendekati nilai wajarnya, sehingga laporan keuangan menjadi lebih relevan. Berdasarkan PSAK Nomor 16, frekuensi revaluasi bergantung pada perubahan nilai wajar dari aset tetap yang direvaluasi. Jika aset tetap mengalami perubahan nilai wajar secara signifikan dan fluktuatif, maka aset tetap perlu direvaluasi secara tahunan. Namun untuk aset tetap yang perubahan nilai wajarnya tidak signifikan, revaluasi aset tetap dapat dilakukan tiga atau lima tahun sekali (IAI, 2017).

Dalam melakukan revaluasi aset tetap, manajemen dipengaruhi oleh beberapa faktor. Seng dan Su (2010) mengemukakan bahwa keputusan manajemen untuk melakukan revaluasi aset tetap dipengaruhi oleh kontrak utang, biaya politik, dan asimetri informasi. Hal yang sama juga diungkapkan oleh Fields, Lys, Thomas, dan Linda (2001, dalam Manihuruk dan Farahmita, 2014) yang mengklasifikasikan motivasi manajemen untuk melakukan revaluasi aset tetap menjadi tiga kategori, yaitu contracting, asset pricing dan influencing external parties. Kategori pertama contracting menjelaskan motivasi pilihan akuntansi dilakukan untuk mempengaruhi perjanjian kontraktual perusahaan, seperti kontrak utang. Kategori kedua asset pricing disebabkan oleh asimetri informasi yang menunjukkan perbedaan nilai wajar aset yang sebenarnya dengan nilai tercatat dalam laporan keuangan. Kategori yang ketiga influencing external party/externalities menyatakan bahwa motivasi pilihan akuntansi oleh manajemen bertujuan untuk mempengaruhi pihak eksternal selain pemegang saham aktual maupun potensial, seperti regulator, pesaing, dan pemasok. Berdasarkan penjelasan tersebut, dapat diidentifikasi bahwa kategori contracting, asset pricing dan influencing external parties dalam penelitian Fields dkk. (2001, dalam Manihuruk dan Farahmita, 2014) memiliki pengertian yang sama dengan faktor kontrak utang, biaya politik, dan asimetri informasi dalam penelitian Seng dan Su (2010).

Respons Pasar

Suatu informasi dapat dikatakan mempunyai nilai guna bagi investor apabila investor merespons informasi dengan melakukan transaksi di pasar modal (Falichin, 2011). Respons ini merupakan bentuk tanggapan investor atas informasi yang diumumkan oleh perusahaan. Jika informasi berdampak positif, maka pasar akan bereaksi positif ditandai dengan peningkatan harga saham. Sebaliknya, jika informasi berdampak negatif, maka pasar akan bereaksi negatif ditandai 
dengan penurunan harga saham. Hal ini sesuai dengan hipotesis pasar efisien (efficient market hypothesis) yang menyiratkan adanya suatu proses penyesuaian harga sekuritas menuju harga keseimbangan yang baru, sebagai respons atas informasi baru yang masuk ke pasar (Tandelilin, 2010). Pada pasar efisien, harga saham akan dengan cepat merefleksikan informasi penting. Namun pada pasar kurang efisien, harga saham akan kurang dapat mencerminkan informasi yang ada atau terdapat lag dalam proses penyesuaian harga, sehingga terbuka celah bagi investor untuk memanfaatkan lag tersebut (Tandelilin, 2010).

\section{Pengembangan Hipotesis}

Pengaruh Kontrak Utang terhadap Keputusan Revaluasi Aset Tetap

Kontrak utang merupakan perjanjian yang dirancang untuk melindungi pemberi pinjaman dan dalam keadaan tertentu dapat mengurangi kemampuan manajemen untuk mengambil keputusan yang menguntungkan perusahaan secara keseluruhan (Nikolaev, 2006). Kontrak ini bertujuan untuk melindungi hak kreditor dari tindakan yang diambil perusahaan dalam rangka meningkatkan kesejahteraan pemegang saham. Salah satu perjanjian dalam kontrak utang ini adalah batasan-batasan rasio keuangan yang harus dipatuhi oleh perusahaan untuk meyakinkan kreditor atas kemampuannnya melunasi utang. Semakin dekat perusahaan dengan batasan rasio, semakin besar risiko perusahaan untuk melakukan pelanggaran atas kontrak utang dan dapat mengakibatkan kreditor mempercepat jatuh tempo utangnya atau memilih tindakan yang paling menguntungkan pihaknya (Chava dan Roberts, 2008). Untuk menghindari hal tersebut, manajemen akan termotivasi untuk memilih kebijakan akuntansi yang mampu mempengaruhi besaran rasio keuangan dalam perjanjian kontrak utang.

H1 : Kontrak utang berpengaruh positif terhadap keputusan revaluasi aset tetap.

Pengaruh Biaya Politik terhadap Keputusan Revaluasi Aset Tetap

Biaya politik merupakan biaya yang dikeluarkan perusahaan dalam rangka memenuhi tuntutan pihak eksternal, seperti pemerintah dan serikat buruh terhadap perusahaan. Biaya politik yang tinggi akan dihadapi oleh perusahaan besar karena perusahaan besar cenderung menghasilkan laba yang tinggi sehingga mendapatkan perhatian dan tekanan yang tinggi dari pemerintah, serikat buruh, dan kelompok komunitas (Chainirun dan Narktabtee, 2009). Untuk mengurangi besarnya perhatian politik ini, manajemen akan memilih kebijakan akuntansi yang mengurangi laba perusahaan. Salah satu alternatif yang dapat dipilih manajemen adalah melakukan revaluasi aset tetap. Revaluasi aset tetap akan meningkatkan nilai aset tetap sehingga beban depresiasi perusahaan juga meningkat. Peningkatan beban depresiasi akan menurunkan laba perusahaan. Penurunan laba ini diharapkan mampu mengurangi perhatian politik yang diberikan pihak eksternal terhadap perusahaan (Lin dan Peasnell, 2000; dalam Seng dan Su, 2010). Berdasarkan uraian tersebut, dirumuskan hipotesis sebagai berikut:

\section{H2 : Biaya politik berpengaruh positif terhadap keputusan revolusi asset tetap}

Pengaruh Asimetri Informasi terhadap Keputusan Revaluasi Aset Tetap

Asimetri informasi menujukkan adanya ketimpangan informasi yang dimiliki oleh pihak internal dan pihak eksternal perusahaan. Asimetri informasi dapat terjadi karena informasi yang dimiliki manajemen sebagai pengelola perusahaan lebih banyak daripada informasi pemegang saham. Untuk mengurangi asimetri informasi, manajemen akan berusaha memilih metode akuntansi yang dapat membantu menginformasikan kepada pasar tentang nilai perusahaan yang sesungguhnya (Farahmita dan Siregar, 2014).

H3 : Asimetri informasi berpengaruh positif terhadap keputusan revaluasi aset tetap.

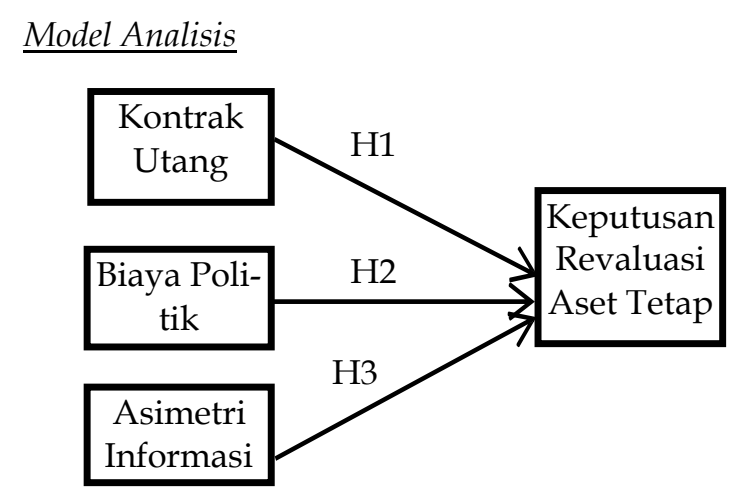

Gambar 1. Model pengaruh kontrak utang, biaya politik.

\section{METODE PENELITIAN}

Desain Penelitian

Desain penelitian ini adalah penelitian kuantitatif dengan pengujian hipotesis yang bertujuan untuk menguji pengaruh kontrak utang, biaya poli- 
tik, dan asimetri informasi terhadap keputusan revaluasi aset tetap pada seluruh perusahaan manufaktur yang terdaftar di BEI. Periode penelitian adalah lima tahun dari tahun 2012-2016.

Identifikasi Variabel, Definisi Operasional dan Pengukuran Variabel

Variabel yang digunakan dalam penelitian ini adalah sebagai berikut:

1. Model penelitian utama bertujuan untuk menguji pengaruh kontrak utang, biaya politik, dan asimetri informasi terhadap keputusan revaluasi aset tetap.

a. Variabel independen, yaitu:

1. Kontrak utang (KU)

2. Biaya politik (BP)

3. Asimetri informasi (AI)

b. Variabel dependen, yaitu: revaluasi aset tetap (REV).

2. Model penelitian tambahan bertujuan untuk menguji perbedaan respons pasar pada perusahaan yang melakukan revaluasi aset tetap dan tidak melakukan revaluasi aset tetap. Dengan demikian model penelitian ini menggunakan satu variabel yaitu respons pasar (CAR).

Definisi operasional beserta pengukuran dari masing-masing variabel adalah:

1. Kontrak utang (KU) adalah sebuah perjanjian yang dirancang untuk melindungi pemberi pinjaman dan dalam keadaan tertentu dapat mengurangi kemampuan manajemen untuk mengambil keputusan yang menguntungkan perusahaan secara keseluruhan (Nikolaev, 2006).

2. Biaya politik (BP) adalah biaya yang dikeluarkan perusahaan dalam rangka memenuhi tuntutan pihak eksternal akibat besarnya laba perusahaan (Milne, 2002). Biaya politik dalam penelitian ini diproksikan dengan ukuran perusahaan berupa total aset yang dirumuskan sebagai berikut (Watts dan Zimmerman, 1990):

$$
\mathrm{BP}=\mathrm{Ln} \text { (Total Aset) }
$$

3. Asimetri informasi (AI) adalah keadaan dimana pengguna laporan keuangan eksternal tidak dapat memperoleh informasi yang lengkap karena perbedaan antara informasi yang dilaporkan dan keadaan yang sebenarnya (Seng dan Su, 2010).

4. Revaluasi aset tetap (REV) adalah proses penilaian ulang aset tetap yang mencerminkan nilai wajar aset pada tanggal revaluasi (IAI, 2017). Revaluasi aset tetap diukur dengan variabel dummy, yaitu 1 untuk perusahaan yang melakukan revaluasi aset tetap, 0 untuk perusahaan yang tidak melakukan revaluasi aset tetap.

5. Respons pasar (CAR) merupakan bentuk tanggapan investor atas informasi yang diumumkan perusahaan. Respons ini dapat dilihat dari perubahan harga saham perusahaan (Andison, 2015; Bandi dan Hartono, 1999). Harga saham dalam penelitian ini dilihat dari cummulative abnormal return lima hari setelah tanggal pengumuman laporan keuangan. Abnormal return merupakan tingkat pengembalian atas sekuritas yang melebihi tingkat harapan investor (Jones, Utama, Frensidy, Ekaputra dan Budiman, 2009). Abnormal return diperoleh sebagai selisih dari retrun aktual dan return harapan. Abnormal return dihitung dengan rumus berikut:

$\mathrm{ARt}=\mathrm{Rt}-\mathrm{E}(\mathrm{R} \mathrm{t})$

Keterangan:

$\mathrm{AR}_{\mathrm{t}}=$ Abnormal return pada waktu $\mathrm{t}$

$\mathrm{Rt} \quad=$ Return aktual pada waktu $\mathrm{t}$

$\mathrm{E}(\mathrm{R} \mathrm{t})=$ Return harapan pada waktu $\mathrm{t}$

\section{Jenis Data dan Sumber Data}

Jenis data yang digunakan dalam penelitian adalah data kuantitatif berupa laporan keuangan, tanggal pengumuman laporan keuangan, dan harga saham perusahaan manufaktur yang terdaftar di BEI tahun 2012-2016. Harga saham yang digunakan adalah harga penutupan (closing price) 31 Desember dan harga saham dan IHSG lima hari setelah tanggal pengumuman laporan keuangan.

\section{Metode Pengumpulan Data}

Metode pengumpulan data adalah dokumentasi dengan mengumpulkan laporan keuangan perusahaan manufaktur tahun 2012-2016 di BEI, tanggal pengumuman laporan keuangan, harga saham penutupan 31 Desember tahun 2012-2016, dan harga saham dan IHSG lima hari setelah tanggal pengumuman laporan keuangan.

\section{Populasi, Sampel, dan Teknik Pengambilan Sampel}

Populasi penelitian adalah semua perusahaan manufaktur yang terdaftar di BEI. Penelitian menggunakan sampel dari populasi yang dipilih dengan purposive sampling dengan kriteria sebagai berikut: 
1. Perusahaan manufaktur yang terdaftar di BEI selama lima tahun berturut-turut dari 2012 sampai 2016.

2. Perusahaan manufaktur yang laporan keuangannya disajikan dalam mata uang rupiah dan berakhir pada 31 Desember.

3. Laporan keuangan yang disajikan adalah laporan keuangan auditan.

4. Memiliki nilai ekuitas positif.

5. Memiliki semua data untuk variabel yang digunakan dalam penelitian.

\section{Teknik Analisis Data}

Model utama dalam penelitian ini adalah sebagai berikut:

1. Model penelitian utama bertujuan menguji pengaruh kontrak utang, biaya politik, dan asimetri informasi terhadap keputusan revaluasi aset tetap dilakukan dengan regresi logistik dengan bantuan software SPSS versi 23 dengan langkah sebagai berikut:

a. Statistik Deskriptif

Statistik deskriptif digunakan untuk memberikan deskripsi atas variabel yang digunakan sehingga informasi tersebut lebih jelas dan dapat lebih mudah dipahami. Pengukuran yang digunakan dalam statistik deskriptif adalah nilai minimal, nilai maksimal, nilai rata-rata, standar deviasi, dan frekuensi (Ghozali, 2016).

b. Model Persamaan Regresi

Model persamaan dalam model pertama adalah sebagai berikut:

$$
\operatorname{Ln} \frac{R E V}{1-R E V}=\alpha+\beta_{1} \mathrm{KU}+\beta_{2} \mathrm{BP}+\beta 3 \mathrm{AI}+\varepsilon
$$

$$
\begin{array}{ll}
\text { Keterangan: } \\
\text { REV } & =\text { Keputusan revaluasi aset tetap } \\
\alpha & =\text { Konstanta } \\
\beta 1,2,3 & =\text { Koefisien regresi } \\
\mathrm{KU} & =\text { Kontrak utang } \\
\mathrm{BP} & =\text { Biaya politik } \\
\mathrm{AI} & =\text { Asimetri informasi } \\
\mathcal{E} & =\text { error }
\end{array}
$$

c. Uji Model Fit

Uji model fit dilakukan dengan menggunakan -2 Log Likelihood (-2LogL), yaitu dengan membandingkan -2LogL awal dan -2LogL akhir (Ghozali, 2016). Pada 2LogL awal, konstanta dimasukkan pada model, sedangkan pada -2LogL akhir, variabel independen ditambahkan dalam model tersebut. Hipotesis untuk menilai model fit adalah:

Ho : Model yang dihipotesiskan fit dengan data.

$\mathrm{H}_{\mathrm{a}} \quad$ : Model yang dihipotesiskan tidak fit dengan data.

H0 diterima ketika -2LogL awal lebih besar dari -2LogL akhir, sedangkan H0 ditolak ketika -2LogL awal lebih kecil dari pada 2LogL akhir.

d. Uji Kelayakan Model Regresi (Uji Hosmer dan Lemeshow)

Uji kelayakan model regresi dilakukan dengan uji Hosmer dan Lemeshow (Ghozali, 2016). Uji ini bertujuan untuk menguji apakah model regresi layak digunakan. Hipotesis untuk menilai kelayakan model rergresi adalah:

Ho :Model regresi layak digunakan $\mathrm{Ha}$ :Model regresi tidak layak digunakan.

e. Uji Koefisien Determinasi (Nagelkerke's $R$ Square)

Uji Nagelkerke's $R$ square merupakan modifikasi dari koefisien Cox dan Snell untuk memastikan bahwa nilainya bervariasi dari 0 sampai 1.

f. Uji Ketepatan Klasifikasi

Uji Ketepatan Klasifikasi menghitung nilai estimasi yang benar dan salah (Ghozali, 2016). Pada model yang sempurna semua kasus akan berada ada diagonal dengan tingkat peramalan $100 \%$.

g. Pengujian Hipotesis

Pengujian hipotesis model penelitian ini menggunakan model analisis regresi logistik. Model ini digunakan karena variabel dependen merupakan variabel dummy.

2. Uji tambahan dilakukan menganalisis perbedaan respons pasar pada perusahaan yang melakukan revaluasi aset tetap dan tidak melakukan revaluasi aset tetap. Teknik analisis data yang dikgunakan adalah independent $t$ test dengan bantuan software SPSS versi 23 dengan langkah sebagai berikut:

a. Statistik Deskriptif

Statistik deskriptif digunakan untuk memberikan deskripsi atas variabel yang digunakan sehingga informasi tersebut 
lebih jelas dan dapat lebih mudah dipahami. Pengukuran yang digunakan dalam statistik deskriptif adalah nilai rata-rata, nilai minimal, nilai maksimal, dan standar deviasi (Ghozali, 2016).

b. Uji Normalitas

Uji normalitas dilakukan untuk melihat apakah dalam persamaan yang digunakan semua data yang digunakan terdistribusi normal. Pengujian yang digunakan adalah uji Kolmogorov-Smirnof. Ghozali (2016) menyatakan bahwa data residual terdistribusi normal jika signifikansi $>0,05$ dan $\leq 0,05$.

c. Uji Tambahan

Dasar pengambilan keputusan independent $t$ test dilakukan dengan hipotesis sebagai berikut:

$\mathrm{H} 0$ : Tidak terdapat perbedaan respons pasar pada perusahaan yang melakukan revaluasi aset tetap dan tidak melakukan revaluasi aset tetap.

$\mathrm{H}_{\mathrm{a}}$ : Terdapat perbedaan respons pasar pada perusahaan yang melakukan revaluasi aset tetap dan tidak melakukan revaluasi aset tetap

\section{HASIL DAN PEMBAHASAN}

Karakteristik Obyek Penelitian

Obyek penelitian adalah perusahaan manufaktur yang terdaftar di Bursa Efek Indonesia. Berdasarkan kriteria purposive sampling yang ditentukan diperoleh 88 perusahaan sebagai sampel penelitian, dengan periode pengamatan 5 tahun sehingga total data penelitian adalah 440 .
Tabel 1. Kriteria Pemilihan Sampel

\begin{tabular}{|c|c|}
\hline Keterangan & $\begin{array}{c}\text { Jumlah } \\
\text { Perusahaan }\end{array}$ \\
\hline $\begin{array}{c}\text { Populasi: Seluruh perusahaan } \\
\text { manufaktur yang terdaftar di } \\
\text { BEI }\end{array}$ & 152 \\
\hline Perusahaan yang tidak memen- & \\
\hline $\begin{array}{l}\text { uhi kriteria: } \\
\end{array}$ & (22) \\
\hline $\begin{array}{l}\text { 1. Perusanaan yang terdattar } \\
\text { di BEI berturut- turut dari }\end{array}$ & \\
\hline 2012 sampai 2016 & \\
\hline $\begin{array}{ll}\text { 2. } & \text { Perusahaan yang } \\
& \text { laporan keuangannya }\end{array}$ & \\
\hline disajikan dalam mata & (27) \\
\hline $\begin{array}{l}\text { uang rupiah dan be- } \\
\text { rakhir pada } 31 \text { Desem- } \\
\text { ber. }\end{array}$ & \\
\hline 3. Laporan keuangan auditan. & \\
\hline 4. Memiliki nilai ekuitas positif & (1) \\
\hline $\begin{array}{l}\text { 5. Memiliki semua data un- } \\
\text { tuk variabel yang } \\
\text { digunakan dalam } \\
\text { penelitian. }\end{array}$ & $\begin{array}{l}\text { (8) } \\
\text { (6) }\end{array}$ \\
\hline Total perusahaan sampel & 88 \\
\hline Total pengamatan 2012-2016 & 440 \\
\hline
\end{tabular}

Sumber: situs BEI dan Saham OK (diolah).

\section{Deskripsi Data}

Tabel 2. Statistik Deskriptif Variabel Penelitian

\begin{tabular}{|c|c|c|c|c|c|}
\hline Var & $\mathrm{N}$ & Minimum & Maximum & Mean & $\begin{array}{c}\text { Std. } \\
\text { Deviation }\end{array}$ \\
\hline $\mathrm{KU}$ & 440 & 0,03723 & 0,96783 & 0,45383 & 0,019905 \\
\hline $\mathrm{BP}$ & 440 & 25,27668 & 33,19881 & 28,19881 & 1,58071 \\
\hline $\mathrm{AI}$ & 440 & 0,03472 & 62,93107 & 3,08402 & 6,98620 \\
\hline $\mathrm{CAR}$ & 440 & $-0,69678$ & 2,07635 & 0,01492 & 0,20977 \\
\hline
\end{tabular}

Sumber: Laporan Keuangan 2012-2016 (diolah).

Tabel 3. Statistik Deskriptif Keputusan Revaluasi Aset Tetap

\begin{tabular}{|c|c|c|}
\hline Keterangan & Frek & Persentase \\
\hline $\begin{array}{l}\text { Tidak melakukan } \\
\text { revaluasi aset tetap }\end{array}$ & 397 & 90,2 \\
\hline $\begin{array}{l}\text { Melakukan revaluasi } \\
\text { aset tetap }\end{array}$ & 43 & 9,8 \\
\hline Total & 440 & 100 \\
\hline
\end{tabular}

Sumber: Laporan Keuangan 2012-2016 (diolah). 
Analisis Data Model Penelitian Utama

Uji Model Fit

Tabel 4. Nilai -2 Log Likelihood

\begin{tabular}{|l|l|}
\hline -2 Log Likelihood & \multicolumn{1}{|c|}{ Nilai } \\
\hline Block 0 & 281,653 \\
\hline Block 1 & 232,276 \\
\hline Keterangan & $\begin{array}{l}\text { Model fit dengan } \\
\text { data }\end{array}$ \\
\hline
\end{tabular}

Sumber: Laporan Keuangan 2012-2016 (diolah)

Uji Kelayakan Model Regresi (Uji Hosmer dan Lemeshow)

Tabel 5. Hosmer and Lemeshow

\begin{tabular}{|c|c|c|c|}
\hline Step & Chi-square & Sig. & Keterangan \\
\hline 1 & 3,917 &, 865 & $\begin{array}{c}\text { Model regresi } \\
\text { layak }\end{array}$ \\
\hline
\end{tabular}

Sumber: Laporan Keuangan 2012-2016 (diolah)

Uji Koefisien Determinasi (Nagelkerke's R Square)

Tabel 6. Nilai Nagelkerke R Square

\begin{tabular}{|l|l|l|l|}
\hline Step & $\begin{array}{l}-2 \text { Log } \\
\text { likelihood }\end{array}$ & $\begin{array}{l}\text { Cox \& Snell R } \\
\text { square }\end{array}$ & $\begin{array}{l}\text { Nagelkerke } \\
\text { R Square }\end{array}$ \\
\hline 1 & $232,776 a$ &, 105 &, 222 \\
\hline \multicolumn{3}{|c|}{ Sumber: Laporan Keuangan 2012-2016 (diolah) }
\end{tabular}

Uji ketepatan klasifikasi

Tabel 7. Tabel Ketepatan Klasifikasi

\begin{tabular}{|c|c|c|c|}
\hline \multirow[b]{2}{*}{ Observed } & \multicolumn{3}{|c|}{ Predicted } \\
\hline & $\begin{array}{c}\text { Tidak } \\
\text { Melakukan } \\
\text { Revaluasi } \\
\text { Aset Tetap }\end{array}$ & $\begin{array}{c}\text { Melakukan } \\
\text { Revaluasi } \\
\text { Aset Tetap }\end{array}$ & $\begin{array}{c}\text { Percentage } \\
\text { Correct }\end{array}$ \\
\hline $\begin{array}{l}\text { Tidak } \\
\text { Melakukan } \\
\text { Revaluasi } \\
\text { Aset Tetap }\end{array}$ & 393 & 4 & 99,0 \\
\hline $\begin{array}{l}\text { Melakukan } \\
\text { Revaluasi } \\
\text { Aset Tetap }\end{array}$ & 42 & 1 & 2,3 \\
\hline $\begin{array}{l}\text { Overall } \\
\text { Percentage }\end{array}$ & & & 89,5 \\
\hline
\end{tabular}

Sumber: Laporan Keuangan 2012-2016 (diolah)

Pengujian Hipotesis

Tabel 8. Hasil Uji Regresi Logistik

\begin{tabular}{|c|c|c|c|c|c|}
\hline Var & B & S.E. & Sig. & $\operatorname{Exp}(\mathrm{B})$ & Keterangan \\
\hline KU & 1,115 &, 929 &, 230 & 3,050 & $\begin{array}{c}\text { Tidak } \\
\text { signifikan }\end{array}$ \\
\hline BP &, 588 &, 119 &, 000 & 1,801 & $\begin{array}{c}\text { Positif, } \\
\text { signifikan }\end{array}$ \\
\hline AI &,- 785 &, 218 &, 000 &, 456 & $\begin{array}{c}\text { Negatif, } \\
\text { signifikan }\end{array}$ \\
\hline Konstanta & $-18,40$ & 3,242 &, 000 &, 000 & \\
\hline
\end{tabular}

Sumber: Laporan Keuangan 2012-2016 (diolah)

\section{$\underline{\text { Uji Tambahan }}$}

Uji Normalitas

Tabel 9. One Sample Kolmogorov Smirnov

\begin{tabular}{|c|c|c|}
\hline $\mathrm{N}$ & REV & CAR \\
\hline $\begin{array}{c}\text { Asymp. Sig. } \\
\text { (2-tailed) }\end{array}$ & 0,000 & 040 \\
\hline Keterangan & $\begin{array}{c}\text { Tidak } \\
\text { terdistribusi } \\
\text { normal }\end{array}$ & $\begin{array}{c}\text { Tidak } \\
\text { terdistribusi } \\
\text { normal }\end{array}$ \\
\hline
\end{tabular}

Sumber: Laporan Keuangan 2012-2016 (diolah)

Uji Mann-Whitney $U$

Tabel 10. Hasil Uji Mann-Whitney U

\begin{tabular}{|l|l|}
\hline & CAR \\
\hline Mann-Whitney U & 8222,000 \\
\hline Wilcoxon W & 9168,000 \\
\hline Z &,- 396 \\
\hline Asymp. Sig. (2-tailed) &, 692 \\
\hline Keterangan & Tidak signifikan \\
\hline
\end{tabular}

Sumber: Laporan Keuangan 2012-2016 (diolah)

\section{Pembahasan}

Pengaruh Kontrak Utang terhadap Keputusan Revaluasi Aset Tetap

Hasil pengujian hipotesis menunjukkan bahwa kontrak utang tidak berpengaruh signifikan terhadap keputusan revaluasi aset tetap. Hal ini sesuai dengan penelitian Seng dan Su (2010) yang menyatakan bahwa tidak ada pengaruh antara kontrak utang yang diukur dengan leverage dengan keputusan revaluasi aset tetap. Seng dan Su (2010) membuktikan bahwa $80 \%$ revaluasi aset tetap hanya menurunkan leverage kurang dari $6 \%$, sehingga memperbaiki rasio leverage mungkin bukan merupakan faktor yang memotivasi manejemen. Selain itu penelitian Yulistia dkk. (2015) juga membuktikan bahwa leverage tidak berpengaruh terhadap keputusan revaluasi aset tetap perusahaan. Yulistia dkk. (2015) menyatakan bahwa kreditor dapat mengabaikan revaluasi aset tetap dalam pengambilan keputusan terkait pinjaman perusahaan. Namun, hasil penelitian ini tidak konsisten dengan penelitian Andison (2015) yang menyatakan bahwa leverage berpengaruh positif terhadap keputusan revaluasi aset tetap. Andison (2015) menyatakan bahwa kreditor lebih menyukai perusahaan dengan leverage yang rendah karena akan meningkatkan perlindungan terhadap kreditor sehingga leverage mampu memotivasi manajemen untuk melakukan revaluasi aset tetap. 
Argumen sebelumnya menyatakan bahwa semakin dekat perusahaan dengan batasan rasio dalam kontrak utang, semakin besar motivasi manajemen untuk melakukan revaluasi aset tetap. Dengan revaluasi aset tetap, nilai rasio keuangan tersebut dapat menurun dan menghindarkan perusahaan dari pelanggaran kontrak utang. Hasil penelitian ini menunjukkan bahwa rata-rata aset yang didanai dari utang sebesar $45,38 \%$, sehingga dapat disimpulkan bahwa perusahaan sampel rata-rata menggunakan ekuitas untuk mendanai asetnya.

Tidak terdapat pengaruh antara kontrak utang dan keputusan revaluasi aset tetap dapat disebabkan oleh anggapan bahwa manajemen yang memilih melakukan revaluasi aset tetap untuk menghindari pelanggaran kontrak utang tampak kurang kredibel. Selain itu kreditor juga telah memahami keputusan revaluasi aset tetap yang diambil perusahaan sehingga kreditor dapat mengeluarkan revaluasi aset tetap dari dasar perhitungan rasio kontrak utang (Seng dan Su, 2010). Dengan ini dapat disimpulkan bahwa pelanggaran kontrak utang tidak dapat dihindari dengan melakukan revaluasi aset tetap.

Pengaruh Biaya Politik terhadap Keputusan Revaluasi Aset Tetap

Hasil pengujian hipotesis menyatakan bahwa biaya politik berpengaruh positif signifikan terhadap keputusan revaluasi aset tetap. Hal ini sesuai dengan penelitian Seng dan Su (2010) yang menunjukkan bahwa biaya politik yang diproksikan dengan ukuran perusahaan berpengaruh positif terhadap keputusan revaluasi aset tetap. Seng dan Su (2010) membuktikan bahwa ukuran perusahaan yang melakukan revaluasi juga lebih tinggi dibandingkan dengan ukuran perusahaan yang tidak melakukan revaluasi sehingga dapat disimpulkan bahwa perusahaan dengan biaya politik besar lebih termotivasi melakukan revaluasi aset tetap. Penelitian Tay (2009) juga mendukung hal tersebut dengan hasil penelitiannya yang membuktikan bahwa pada tahun 2005 ukuran perusahaan berpengaruh positif terhadap keputusan revaluasi aset tetap. Tay (2009) menyatakan bahwa perusahaan dengan ukuran lebih besar lebih berpeluang untuk diaudit oleh auditor internasional sehingga tuntutan untuk menyajikan aset sesuai nilai wajarnya menjadi lebih besar. Namun, penelitian Yulistia dkk. (2015) menunjukkan bahwa tidak terdapat pengaruh signifikan antara ukuran perusahaan dan keputusan revaluasi aset tetap. Yulistia dkk. (2015) menyatakan bahwa walaupun re- valuasi aset tetap dapat menurunkan laba perusahaan sehingga dapat mengurangi biaya politik, aset perusahaan justru bertambah besar dan mengakibatkan perusahaan semakin mendapatkan perhatian politik.

Argumen sebelumnya menyatakan bahwa semakin tinggi biaya politik yang dihadapi perusahaan, semakin besar kemungkinan perusahaan untuk melakukan revaluasi aset tetap. Berdasarkan statistik deskriptif pada tabel 4.2. menunjukkan bahwa rata-rata ukuran perusahaan 28,19881. Dibandingkan dengan nilai minimum 25,27668 dan nilai maksimum 33,19881, nilai rata-rata tersebut tergolong rendah dan $90,2 \%$ perusahaan sampel tidak melakukan revaluasi aset tetap. Dengan demikian dapat disimpulkan bahwa perusahaan sampel rata-rata berukuran kecil dan tidak melakukan revaluasi aset tetap.

Perusahaan besar akan cenderung mendapatkan perhatian politik yang lebih besar karena perusahaan besar lebih mampu menghasilkan laba yang tinggi dibandingkan perusahaan yang lebih kecil. Dalam rangka mengurangi biaya politik ini, maka manajemen dapat memutuskan untuk melakukan revaluasi aset tetap untuk mengurangi mengurangi laba perusahaan melalui peningkatan beban depresiasi.

Pengaruh Asimetri Informasi terhadap Keputusan Revaluasi Aset Tetap

Hasil pengujian hipotesis menyatakan bahwa asimetri informasi berpengaruh negatif signifikan terhadap keputusan revaluasi aset tetap. Hal ini tidak sesuai dengan penelitian Andison (2015) yang menyatakan bahwa market to book ratio berpengaruh positif terhadap keputusan revaluasi aset tetap. Perusahaan dengan nilai market to book ratio yang tinggi menunjukkan bahwa perusahaan tersebut undervalue sehingga mempengaruhi keputusan revaluasi aset tetap. Selain itu penelitian Tay (2009) menyatakan bahwa market to book ratio tidak berpengaruh terhadap keputusan revaluasi aset tetap. Tay (2009) menyatakan manajemen tidak termotivasi melakukan revaluasi aset tetap berdasarkan tinggi atau rendahnya market to book ratio. Seng dan Su (2010) juga menyatakan bahwa asimetri informasi tidak berpengaruh terhadap keputusan revaluasi aset tetap. Seng dan Su (2010) berpendapat bahwa revaluasi aset tetap dilakukan secara rutin dan telah direncanakan dalam kebijakan revaluasi, intensitas aset tetap tidak memotivasi revaluasi aset tetap, tidak terdapat perbedaan pertumbuhan perusahaan pada perusahaan yang melakukan revaluasi dan tidak melakukan revaluasi, tawaran 
takeover tidak memotivasi revaluasi aset tetap karena peningkatan aset yang tidak signifikan, dan kompensasi bonus masih jarang dilakukan pada periode penelitian sehingga tidak terdapat pengaruh signifikan antara asimetri informasi dan keputusan revaluasi aset tetap.

Argumen sebelumnya menyatakan bahwa perusahaan dengan asimetri informasi yang tinggi akan memilih melakukan revaluasi aset tetap untuk menunjukkan true value dari perusahaan. Hasil penelitian ini menyatakan bahwa asimetri informasi berpengaruh negatif terhadap keputusan revaluasi aset tetap diduga karena kenyataan bahwa perusahaan dengan asimetri informasi yang tinggi justru tidak melakukan revaluasi aset tetap. Berdasarkan statistik deskriptif pada tabel 4.2. rata-rata asimetri informasi yang diproksikan dengan market to book ratio yaitu 3,08401 lebih besar daripada nilai rata-rata market to book ratio perusahaan manufaktur tahun 20132016 berdasarkan penelitian Vianney (2017) dan Sari (2017) yaitu 1,8048 dan 1,87829 Selain itu $90,2 \%$ perusahaan sampel tidak melakukan revaluasi aset tetap, sehingga dapat disimpulkan bahwa perusahaan sampel rata-rata memiliki asimetri informasi tinggi dan tidak melakukan revaluasi aset tetap.

Perusahaan dengan asimetri informasi tinggi tidak melakukan revaluasi diduga karena asumsi manajemen bahwa revaluasi aset tetap akan meningkatkan nilai perusahaan di mata investor sehingga harga pasar akan meningkat lebih tinggi dibandingkan dengan peningkatan nilai buku. Akibatnya asimetri informasi yang diproksikan dengan market to book ratio justru semakin besar. Untuk menghindari hal ini, manajemen perusahaan dengan asimetri informasi tinggi justru memilih tidak melakukan revaluasi aset tetap.

Perbedaan Respons Pasar pada Perusahaan yang Melakukan Revaluasi Aset Tetap dan Tidak Melakukan Revaluasi Aset Tetap

Hasil uji Mann-Whitney $U$ menunjukkan bahwa tidak terdapat perbedaan signifikan antara respons pasar perusahaan yang melakukan revaluasi aset tetap dan tidak melakukan revaluasi aset tetap. Hal ini tidak sesuai dengan hasil penelitian Andison (2015) yang menyatakan bahwa terdapat respons pasar yang lebih tinggi pada perusahaan yang melakukan revaluasi dibandingkan dengan perusahaan yang tidak melakukan revaluasi. Andison (2015) berpendapat bahwa perusahaan yang melakukan revaluasi aset tetap di masa depan akan menghasilkan laba yang lebih tinggi menunjukkan kinerja yang baik sehingga menimbulkan respons pasar yang positif dari investor. Hasil penelitian tersebut sejalan dengan penelitian Tay (2009) yang menyimpulkan bahwa terdapat abnormal return yang lebih tinggi setelah tanggal revaluasi dibandingkan dengan sebelum tanggal revaluasi. Tay (2009) mengungkapkan bahwa investor akan bereaksi secara positif atas informasi revaluasi aset tetap jika mereka meyakini bahwa revaluasi aset tetap akan memberikan manfaat di masa depan.

Argumen sebelumnya menyatakan bahwa terdapat perbedaan respons pasar pada perusahaan yang melakukan revaluasi aset tetap dan tidak melakukan revaluasi aset tetap dengan dugaan bahwa keputusan revaluasi aset tetap menjadi informasi positif bagi pasar karena menunjukkan nilai aset yang sebenarnya. Diduga bahwa pada tahun penelitian, pasar tidak menganggap informasi revaluasi aset tetap sebagai informasi yang berguna dan bernilai tambah karena informasi ini bukan informasi besar seperti pengumuman dividen, pengumuman laba, dan pemecahan saham. Investor cenderung mempertimbangkan profitabilitas dan dividen dalam mengambil keputusan investasi (Melania, 2016). Kenaikan nilai aset karena revaluasi aset tetap bukan disebabkan oleh peningkatan kinerja perusahaan, melainkan karena perbedaan nilai pasar dengan nilai buku aset. Dengan demikian dapat disimpulkan bahwa informasi revaluasi aset tetap tidak digunakan sebagai bahan pertimbangan dalam proses pengambilan keputusan transaksi perdagangan saham sehingga tidak menimbulkan respons yang berbeda antara perusahaan yang melakukan revaluasi aset tetap dan tidak melakukan revaluasi aset tetap.

\section{SIMPULAN}

Berdasarkan hasil analisis, dapat disimpulkan bahwa kontrak utang tidak berpengaruh signifikan terhadap keputusan revaluasi aset tetap pada perusahaan manufaktur yang terdaftar di BEI periode 2012-2016. Hal ini dikarenakan pandangan bahwa manajemen yang memilih melakukan revaluasi aset tetap tampak kurang kredibel. Selain itu, kreditor dapat mengecualikan revaluasi aset tetap dalam pertimbangan kontrak utang sehingga keberadaan revaluasi aset tetap tidak dapat menghindarkan perusahaan dari pelanggaran kontrak utang.

Biaya politik terbukti berpengaruh positif signifikan terhadap keputusan revaluasi aset 
tetap pada perusahaan manufaktur yang terdaftar di BEI periode 2012-2016. Hal ini menunjukkan bahwa motif manajemen melakukan revaluasi untuk mengurangi biaya politik benar terjadi. Biaya politik yang tinggi dapat dikurangi perusahaan dengan memilih kebijakan akuntansi yang menurunkan laba, yaitu melakukan revaluasi aset tetap. Revaluasi aset tetap akan meningkatkan beban depresiasi dan menurunkan rasio profitabilitas sehingga biaya politik juga akan menurun.

Asimetri informasi berpengaruh negatif signifikan terhadap keputusan revalusi aset tetap pada perusahaan manufaktur yang terdaftar di BEI periode 2012-2016. Hal ini membuktikan bahwa semakin tinggi asimetri informasi perusahaan, semakin rendah peluang manajemen untuk melakukan revaluasi aset tetap dengan dugaan bahwa revaluasi aset tetap akan memberikan informasi positif bagi investor sehingga kenaikan harga saham perusahaan akan melebihi kenaikan nilai buku perusahaan. Dengan demikian, revaluasi aset tetap justru akan memperbesar asimetri informasi.

Hasil uji tambahan menunjukkan tidak terdapat perbedaan respons pasar antara perusahaan yang melakukan revaluasi dengan yang tidak melakukan revaluasi dengan dugaan bahwa investor menganggap pengingkatan aset semata-mata karena perbedaan nilai pasar dan nilai buku aset, bukan karena peningkatan kinerja. Dengan demikian dapat disimpulkan bahwa pasar tidak memberikan respons atas informasi revaluasi aset tetap karena mereka menganggap informasi seperti profitabilitas dan pembagian dividen lebih berguna daripada keputusan revaluasi aset tetap untuk pengambilan keputusan transaksi perdagangan saham. Penelitian ini tidak lepas dari keterbatasan penelitian sebagai berikut:

1. Variabel yang diuji memiliki koefisien determinasi sebesar 22,2\% dan hanya variabel biaya politik yang terbukti berpengaruh positif signifikan terhadap keputusan revaluasi aset tetap sehingga diduga terdapat variabel lain yang masih perlu ditambahkan dalam penelitian ini.

2. Variabel kontrak utang dan asimetri informasi menolak hipotesis yang diberikan, sehingga diperkirakan terdapat proksi lain yang dapat mewakili kontrak utang dan asimetri informasi.

Beberapa saran yang diperlukan untuk memperluas penelitian selanjutnya sebagai berikut:
1. Menggunakan variabel-variabel lain yang diduga berpengaruh terhadap keputusan revaluasi aset tetap seperti penurunan arus kas operasi dan likuiditas (yulistia dkk., 2015; andison, 2015; dan tay, 2009).

2. Menggunakan proksi lain untuk mengukur kontrak utang dan asimetri informasi, misalnya debt to ebitda, debt to equity ratio, debt to tangible net worth untuk kontrak utang (chava dan roberts, 2008) dan intensitas aset tetap, kesempatan investasi, rencana bonus, revaluasi sebelumnya, dan tawaran takeover untuk asimetri informasi (seng dan su, 2010).

\section{REFERENCES}

Andison, (2015), Fixed Asset Revaluation: Market Reactions, Simposium Nasional Akuntansi 18, Medan.

Badan Pengawas Pasar Modal dan Lembaga Keuangan, (2012), Keputusan Nomor 347/BL/2012 tentang Penyajian dan Pengungkapan Laporan Keuangan Emiten atau Perusahaan Publik.

Bandi dan Hartono, J., (1999), Perilaku Reaksi Harga dan Volume Perdagangan Saham terhadap Pengumuman Dividen, Simposium $\mathrm{Na}$ sional Akuntansi 2, Malang.

Chainirun, P., dan Narktabtee, K., (2009), The Evidence of Management Motivation to Revalue Property Plant and Equipment in Thailand, NIDA Business Journal, Vol 5 No 52, page 134155.

Chava, S., dan Roberts, M. R., (2008), How Does Financing Impact Investment? The Role of Debt Covenants, The Journal of Finance, Vol 63 No 5, page 2085-2121.

Dichev, I. D., dan Skinner, D. J., (2002), Largesample Evidence on The Debt Covenant Hypothesis, Journal of Accounting Research, Vol 40 No 4, page 1091-1123.

Falichin, M. Z. M., (2011), Pengaruh Corporate Social Responsibility Disclosure Terhadap Reksi Investor dengan Environmental Performance Rating dan Corporate Governance sebagai Variabel Moderasi, Skripsi, Akuntansi, Universitas Diponegoro.

Farahmita, A., dan Siregar, V. S., (2014), Faktorfaktor yang Mempengaruhi Kemungkinan Perusahaan Memilih Metode Nilai Wajar untuk Properti Investasi, Simposium Nasional Akuntansi 17, Mataram.

Ghozali, I., (2016), Aplikasi Analisis Multivariate dengan Program IBM SPSS 23, Edisi 8, Sema- 
rang: Badan Penerbit Universitas Diponegoro.

Ikatan Akuntan Indonesia, (1994), Standar Akuntansi Keuangan, Jakarta: Salemba Empat. , (2017), Standar Akuntansi Keuangan, Jakarta.

Jones, C. P., Utama, S., Frensidy, B., Ekaputra, I. A. dan Budiman, R. U., (2009), Investment Analysis and Management (An Indonesian Adaptation), Jakarta: Salemba Empat.

Kementerian Keuangan, (2008), Peraturan Nomor 79/PMK.03/2008 tentang Penilaian Kembali Aset Tetap untuk Tujuan Perpajakan.

Khairati, A., Muslim, R. Y. dan Darmayanti, Y., (2015), Pengaruh Leverage, Firm Size, dan Asset Intensity terhadap Keputusan Perusahaan Melakukan Revaluasi Aset Tetap, E-Journal Universitas Bung Hatta, Vol 6 No 1, page 1-14.

Kieso, D. E. , Weygandt, J. J., dan Warfield, T. D., (2014), Intermediate Accounting IFRS Second Edition, USA: John Wiley dan Sons Inc.

Manihuruk, T. N., dan Farahmita, A., (2014), Analisis Faktor-Faktor yang Mempengaruhi Pemilihan Metode Revaluasi Aset Tetap pada Perusahaan yang Terdaftar di Bursa Saham Beberapa Negara ASEAN, Simposium Nasional Akuntansi 18, Medan.

Melania, A. B., 2016, Pengaruh Profitabilitas, Leverage, dan Dividen Terhadap Reaksi Pasar, Skripsi, Akuntansi, Sekolah Tinggi Ilmu Ekonomi Indonesia, Surabaya, (http://repository.stiesia.ac.id, diunduh tanggal 9 November 2017).

Milne, M. J., (2002), Positive Accounting Theory, Political Cost and Social Disclosure Analysis: A Critical Look, Critical Perspectives on Accounting, Vol 13 No 3, page 369-395.

Nikolaev, V., (2006), Debt Contract Restrictiveness and Timely Loss Recognition, Working Paper, Belanda: Tilburg University.

Purnamasari, E., (2017), Pengaruh Arus Kas Operasi, Ukuran Perusahaan, dan Intensitas Aset Tetap Terhadap Keputusan Revaluasi Aset Tetap pada Perusahaan Manufaktur di Bursa Efek Indonesia, Skripsi, Akuntansi, Universitas Katolik Widya Mandala, Surabaya, (http://repository.wima.ac.id, diunduh tanggal 24 Agustus 2017).

Sari, G., (2017), Pengaruh DPR, DER, dan ROA Terhadap Nilai Perusahaan pada Perusahaan Manufaktur Sektor Makanan Dan Minuman yang Terdaftar Di Bursa Efek Indonesia Periode 2014-2016, Skripsi, Akademi Akuntansi Permata Harapan, Batam, (https://library.giciku.ac.id, diunduh tanggal 9 November 2017).

Scott, W. R., (2014), Financial Accounting Theory, $7^{\text {th }}$ ed., Toronto: Pearson Prentice Hall.

Seng, D., dan Su, J., (2010), Managerial Incentives Behind Fixed Asset Revaluation, International Journal of Business Research, Vol 10 No. 2, page 1-33.

Suwardjono, (2008), Teori Akuntansi: Perekayasaan Pelaporan Keuangan, Yogyakarta: BPFE.

Tandelilin, E., (2010), Portofolio dan Investasi, Edisi Pertama, Yogyakarta: Kanisius.

Tay, I., (2009), Fixed Asset Revaluation: Management Incentives and Market Reactions, Thesis, Manajemen, Lincoln University, Canterbury, (https://researcharchive.lincoln.ac.nz, diunduh tanggal 22 Agustus 2017).

Vianney, C., (2017), Pengaruh Modal Intelektual Terhadap Nilai Perusahaan dengan Kinerja Keuangan Sebagai Variabel Mediasi, Skripsi, Akuntansi, Universitas Katolik Widya Mandala, Surabaya, (http://repository.wima.ac.id, diunduh tanggal 9 November 2017).

Waluyo, (2014), Perpajakan Indonesia, Jakarta: Salemba Empat.

Watts, R. L., dan Zimmerman, J. L., (1990), Positive Accounting Theory: A Ten Year Perspective, The Accounting Review, Vol 65 No 1, page 131-156.

Yulistia, R., Fauziati, P., Minovia, A. F., dan Khairati, A., (2015), Pengaruh Leverage, Arus Kas Operasi, Ukuran Perusahaan dan Fixed Asset Intensity terhadap Revaluasi Aset Tetap, Simposium Nasional Akuntansi 18, Medan. 